\title{
Earthworms from Mato Grosso, Brazil, and new records of species from the state
}

\author{
Marie Luise Carolina Bartz ${ }^{(1)}$, Amarildo Pasini ${ }^{(1)}$ and George Gardner Brown ${ }^{(2)}$
}

(1)Universidade Estadual de Londrina, Departamento de Agronomia, Rodovia Celso Garcia Cid, PR 445 Km 480, Caixa Postal 6001, CEP 86051-990 Londrina, PR, Brazil. E-mail: bartzmarie@gmail.com, pasini@uel.br (2)Embrapa Florestas, Estrada da Ribeira, Km 111, Caixa Postal 319, CEP 83411-000 Colombo, PR, Brazil. E-mail: browng@cnpf.embrapa.br

\begin{abstract}
The objective of this work was to undertake a qualitative assessment of earthworm diversity in areas under human influence, in a region of Cerrado-Pantanal-Amazon rainforest transition, in the state of Mato Grosso, Brazil. The earthworms were collected in the municipalities of Barra do Bugres and Arenápolis, and were studied together with species previously identified from other municipalities. Seventeen municipalities, at 29 sampling points of Mato Grosso State, have been sampled. Seven species of earthworms were collected and identified in Barra do Bugres: Goiascolex vanzolinii, Pontoscolex (Pontoscolex) corethrurus, Opisthodrillus borellii borellii, Opisthodrillus sp., Dichogaster (Diplothecodrilus) gracilis, Dichogaster sp. and a species of the Criodrilidae family. Four species of earthworms were identified in Arenápolis: Pontoscolex (Pontoscolex) corethrurus, Dichogaster (Diplothecodrilus) gracilis, Dichogaster (Diplothecodrilus) affinis and Dichogaster sp. In total, 32 earthworm species/subspecies are known from Mato Grosso, 22 native and 10 exotic.
\end{abstract}

Index terms: biodiversity, tropical forest, Oligochaeta.

\section{Minhocas do Mato Grosso e novos registros de espécies do estado}

Resumo - O objetivo deste trabalho foi determinar qualitativamente a diversidade de minhocas em áreas sob influência humana, em uma região de transição de Pantanal-Cerrado-Floresta Amazônica, no Estado de Mato Grosso. As minhocas foram coletadas nos municípios de Barra do Bugres e Arenápolis e estudadas em conjunto com espécies previamente identificadas de outros municípios do Estado, em um total de 29 pontos de coletas em 17 municípios. Em Barra do Bugres, foram coletadas e identificadas sete espécies de minhocas: Goiascolex vanzolinii, Pontoscolex (Pontoscolex) corethrurus, Opisthodrillus borellii borellii, Opisthodrillus sp., Dichogaster (Diplothecodrilus) gracilis, Dichogaster sp. e uma espécie da família Criodrilidae. Em Arenápolis foram identificadas quatro espécies: Pontoscolex (Pontoscolex) corethrurus, Dichogaster (Diplothecodrilus) gracilis, Dichogaster (Diplothecodrilus) affinis e Dichogaster sp. Ao todo, 32 espécies/subespécies de minhocas são conhecidas em Mato Grosso, 22 nativas e 10 exóticas.

Termos para indexação: biodiversidade, floresta tropical, Oligochaeta.

\section{Introduction}

Earthworms are present in almost all terrestrial ecosystems, and are one of the most important components of the soil invertebrate macrofauna. Approximately 8,300 species of oligochaetes have been described (of which more than 5,700 are valid species), in 38 families and 811 genera (Reynolds \& Wetzel, 2009). Roughly 50\% of these (around 4,000) are megadrile earthworms (Reynolds, 1994), although many more species are still expected to be found (Fragoso et al., 2003). For instance, James \& Brown (2006) estimated that more than 3,000 species may occur in the Neotropics, although only 960 are presently known (Fragoso \& Brown, 2007). Currently, 305 species/ subspecies of earthworms (megadrili), in 65 genera, are known from Brazil (Brown \& James, 2007); of these, 259 are native $(85 \%)$ and 46 exotic $(15 \%)$.

However, extensiveareas in Brazilare still unexplored and have never been sampled for earthworms (James \& Brown, 2006). If estimates for earthworm biodiversity are correct, the majority of species in the country are yet to be found and described (Brown \& James, 2007). Consequently, new locations should be sampled, which represents a great challenge, since there are few Brazilian researchers working in this area. 
Mato Grosso is a state with few samplings and great potential for earthworm diversity. The state has an area of $903,386 \mathrm{~km}^{2}$ and a tropical climate. The center of the state features plateaus, the west plains and swamps, and the north depressions and residual plateaus. The vegetation in Mato Grosso is characterized by three major Brazilian biomes: the Cerrado (Brazilian savannah) in the Eastern half, the Amazon in the Northwest, and the Pantanal (marsh) in the West. The state's major economic activities are agriculture and extractive industry (forestry, mining and rubber) (Abutakka \& Lima, 2006).

The aim of this study was to undertake a qualitative assessment of earthworm diversity in an areaunderhuman influence, in a region of Cerrado-Pantanal-Amazon rainforest transition, and to synthesize the information on earthworm diversity (collection sites, species present) in the state of Mato Grosso, Brazil.

\section{Materials and Methods}

Sampling sites were located in the surroundings of Gilmar Mourão Farm, in the municipality of Arenápolis $\left(14^{\circ} 39^{\prime} 09.5^{\prime \prime} \mathrm{S}, \quad 56^{\circ} 51^{\prime} 23.0^{\prime \prime} \mathrm{W}\right)$, and in Jauquara Farm, located in the municipality of Barra do Bugres $\left(57^{\circ} 10^{\prime} 50^{\prime \prime} \mathrm{S}, 15^{\circ} 06^{\prime} 36^{\prime \prime} \mathrm{W}\right)$, Mato Grosso state, Brazil. Both cities are in a region of transition between Cerrado, Pantanal and Amazon rainforest biomes, characterized by a high degree of human influence, due to agricultural activities in the area. The site sampled in Jauquara Farm, Barra do Bugres, consisted of a pasture with predominance of Brachiaria humidicula interspersed with islands of native vegetation locally known as "Cucurutis." The soil is classified as Gleissolo Háplico (Typic Haplaquox) in the Brazilian soil classification system (Sistema brasileiro de classificação de solos, 1999; Mapa de solos do Brasil, 2001) with sandy texture. Between December and mid-May, the soil is saturated, due to a shallow water table.

In Gilmar Mourão Farm, Arenápolis, samples were taken in the surroundings of the main farm house, which featured bushy vegetation, few large trees and stacks of fence points within a pasture of Brachiaria brizantha. In open areas, used for cattle grazing and cropping, which had recently been prepared for planting through plowing, harrowing and liming, no earthworms were found. The soil is classified as Latossolo Vermelho-Amarelo (Typic Hapludox)
(Sistema brasileiro de classificação de solos, 1999) with sandy texture.

For qualitative purposes, i.e. to verify earthworm species diversity at each site, the digging method described by Righi (1990) was used in December 2007, in Jauquara Farm, and in January 2008, in Gilmar Mourão Farm, during the rainy season. Samples were taken from holes dug to $30-40 \mathrm{~cm}$ depth, and the earthworms were carefully removed by hand and sorted. Later, the specimens found were preserved in $4 \%$ formaldehyde solution, and after three months, they were transferred into $70 \%$ alcohol solution.

For identification purposes, keys and descriptions of families, genera and species according to Righi (1990) and Blakemore (2002), were used. The specimens collected were deposited in the Fritz Müller Oligochaete Collection (Curitiba, Paraná) of Embrapa Florestas.

Earthworm distribution data for the municipalities of Mato Grosso were obtained from the literature describing previous collections, undertaken mainly by Dr. Gilberto Righi. Other data were taken from the list of specimens deposited in the Fritz Müller Oligochaete Collection and the Gilberto Righi Collection at the Museu de Zoologia, Universidade de São Paulo.

The collecting was performed in five types of vegetation: Amazon rainforest, Cerrado/Forest transition, Cerrado, Cerrado grassland and Cerrado of Pantanal (Figure 1, Table 1), according to Manual técnico da vegetação brasileira (1992).

\section{Results and Discussion}

In Jauquara Farm, Barra do Bugres, seven earthworm species were identified, of which four belonged to the Glossoscolecidae family: Goiascolex vanzolinii Righi, 1984, Pontoscolex (Pontoscolex) corethrurus (Müller, 1857), Opisthodrillus borellii borellii Rosa, 1895 and Opisthodrillus sp. Two of the remainder belonged to the Acanthodrilidae family-Dichogaster (Diplothecodrilus) gracilis (Michaelsen, 1892) and Dichogaster sp. - and one to the Criodrilidae family (Table 1).

In Gilmar Mourão Farm, Arenápolis, four earthworm species were identified: $P$. corethrurus, Dichogaster (Diplothecodrilus) affinis (Michaelsen, 1890), D. gracilis and Dichogaster sp. (Table 1).

The species $P$. corethrurus may be considered a peregrine earthworm at the sites (Brown et al., 2006). Originating from the Guyana Plateau, it spread throughout the tropical and subtropical regions of the 


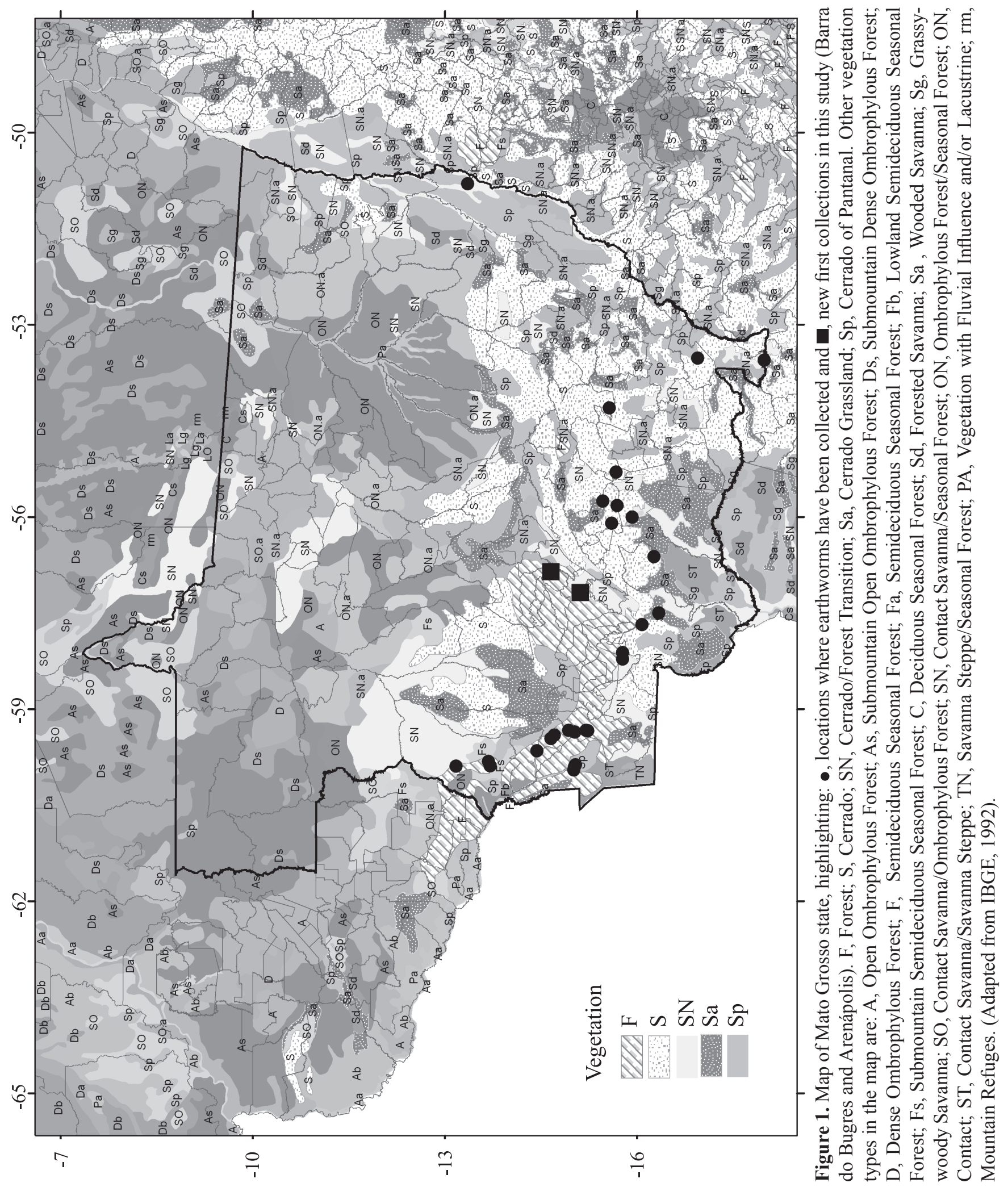




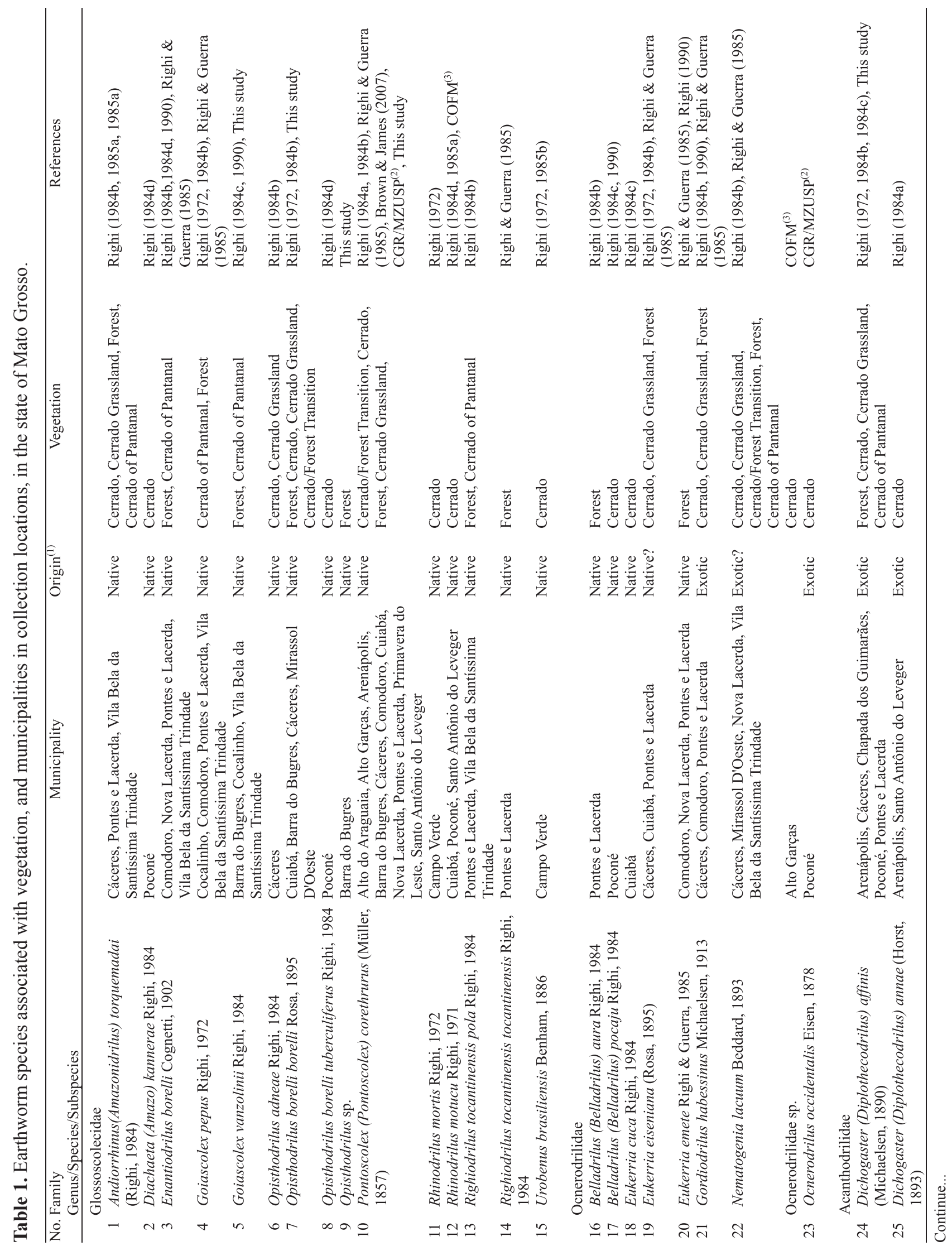




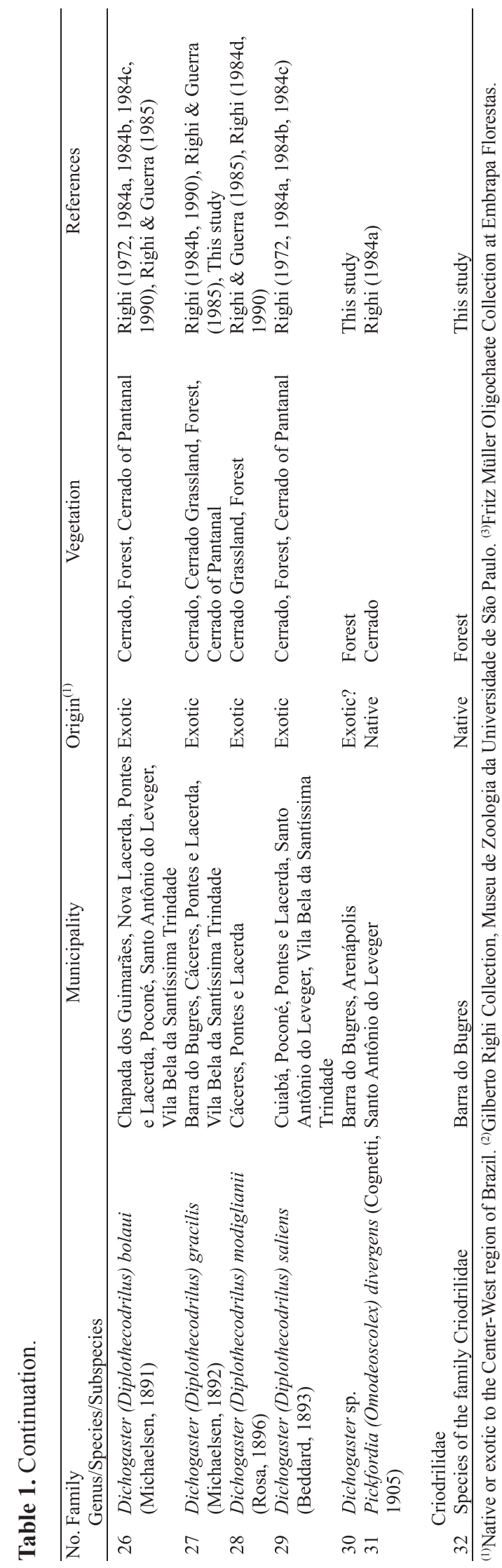

globe, and is the most successful South American earthworm (Righi, 1990). G. vanzolinii and O. borellii borellii are native species, while Opisthodrillus sp. and the species of Criodrilidae may be new species and require further research. This is the first time that the latter species has been recorded in the state; two other species of this family have already been found in marsh areas in Rio Grande do Sul (Lima \& Rodríguez, 2007) and Mato Grosso do Sul (Brown \& James, 2007). Members of this family tend to be more aquatic and are frequently found in flooded areas or sites with shallow water tables.

The remaining species in the study belong to the Acanthodrilidae family, and in Brazil these are as likely to be exotic as native (James \& Brown, 2006). Of the three species identified in this study, two are exotic of wide distribution: D. gracilis and D. affinis (Brown et al., 2006). The third species, Dichogaster sp., warrants further study, as its taxonomic characteristics do not fit the descriptions of species of this genus known in the country. The specimens of this genus, found in the two collection sites, are very similar, and probably belong to the same species.

Mato Grosso state is divided into 141 municipalities; but only 17 have collection sites (Table 1 and Figure 1). Therefore, only $12 \%$ of the municipalities have had at least one collection site for earthworms. In these 17 municipalities, earthworms have been collected from a total of 29 sites (Figure 1), revealing 32 earthworm species/subspecies in 17 genera and 4 families; of this total, 22 species/subspecies are native and 10 may be considered exotic (Table 1). Approximately half (15 species/ subspecies) belong to the Glossoscolecidae family, and the other half can be divided into the Ocnerodrilidae and Acanthodrilidae families, each with 8 species, and the Criodrilidae family, with one species.

Fifty two percent of the sampled points were in forest and $31 \%$ in Cerrado. A large part of the state, especially the Northern region, which is predominantly covered in Amazon rainforest, does not have a single record of earthworm collection yet. Considering the number of new species found by Righi (1990) in his surveys of the region, there is significant potential to find new species, which will require greater collection efforts in the state. These efforts should be encouraged, particularly given the growing human pressure on natural resources and native vegetation, including the paving of the BR-163 road (Cuiabá-Santarém), and the spread of intensive agriculture in the region. 


\section{Conclusion}

Three new earthworm species, Opisthodrilus, Dichogaster and Criodrilidae sp., were added to the list of species known from the state of Mato Grosso, raising the total to 32 known species. New location records for P. corethrurus, G. vanzolinii, O. borellii borellii, D. gracilis and D. affinis are also presented.

\section{Acknowledgements}

To Marilice Cordeiro Garrastazu, for help with Figure 1; to Priscila Trigo Martins Azevedo, for help with the earthworm collection site information; to Eric Gonçalves, Museu de Zoologia da Universidade de São Paulo, for access to Gilberto Righi's collection record book; and to Johann Bartz, and Mariana Rinschede Bartz, for the support during the collections in Barra do Bugres and Arenápolis.

\section{References}

ABUTAKKA, A.; LIMA, M.B. (Ed.). Mato Grosso em números. Cuiabá: Secretaria de Estado de Planejamento e Coordenação Geral, 2006. 74p.

BLAKEMORE, R.J. Cosmopolitan earthworms - an eco-taxonomic guide to the peregrine species of the world. Kippax: VermEcology, 2002. 426p. CD-ROM.

BROWN, G.G.; JAMES, S.W. Ecologia, biodiversidade e biogeografia das minhocasno Brasil.In:BROWN, G.G.;FRAGOSO, C. (Ed.). Minhocas na América Latina: biodiversidade e ecologia. Londrina: Embrapa Soja, 2007. p.297-381.

BROWN, G.G.; JAMES, S.W.; PASINI, A.; NUNES, D.H.; BENITO, N.P.; MARTINS, P.T.; SAUTTER, K.D. Exotic, peregrine and invasive earthworms in Brazil: diversity, distribution and effects on soils and plants. Caribbean Journal of Science, v.42, p.339-358, 2006.

FRAGOSO, C.; BROWN, G.G. Ecología y taxonomía de las lombrices de tierra en Latinoamérica: el primer Encuentro Latino-Americano de Ecología y Taxonomía de Oligoquetas (ELAETAO1). In: BROWN, G.G.; FRAGOSO, C. (Ed.). Minhocas na América Latina: biodiversidade e ecologia. Londrina: Embrapa Soja, 2007. p.33-75.
FRAGOSO, C.; BROWN, G.G.; FEIJOO, A. The influence of Gilberto Righi on tropical earthworm taxonomy: the value of a full-time taxonomist. Pedobiologia, v.47, p.400-404, 2003.

JAMES, S.W.; BROWN, G.G. Earthworm ecology and diversity in Brazil. In: MOREIRA, F.M.S.; SIQUEIRA, J.O.; BRUSSAARD, L. (Ed.). Soil biodiversity in Amazonian and other Brazilian ecosystems. Wallingford: CAB International, 2006. p.56-116.

LIMA, A.C.R. de; RODRÍGUEZ, C. Earthworm diversity from Rio Grande do Sul, Brazil, with a new native criodrilid genus and species (Oligochaeta: Criodrilidae). Megadrilogica, v.11, p.9-18, 2007.

MANUAL técnico da vegetação brasileira. Rio de Janeiro: IBGE, 1992. 92p. (Série manuais técnicos em geociências, 1).

REYNOLDS, J.W. Earthworms of the world. Global Biodiversity, v.4, p.11-16, 1994.

REYNOLDS, J.W.; WETZEL, M.J. Nomenclatura oligochaetologica, suplementum quartum. Champaign: University of Illinois, 2009. Available at: <http://www.inhs.uiuc. edu/ mjwetzel/mjw.inhsCAR.html\#NOSQ>. Acessed on: 09 Sept. 2009.

RIGHI, G. Contribuição ao conhecimento dos oligochaeta brasileiros. Papéis Avulsos de Zoologia, v.25, p.148-166, 1972.

RIGHI, G. Minhocas de Mato Grosso e Rondônia. Brasília: CNPq, 1990. (Relatório de Pesquisa, 12). Programa Polonoroeste.

RIGHI, G. Oligochaeta megadrili da Chapada dos Guimarães, Mato Grosso, Brasil. Boletim de Zoologia, v.8, p.17-23, 1984a.

RIGHI, G. Oligochaeta megadrili da região Centro-Oeste de Mato Grosso, Brasil. Boletim de Zoologia, v.8, p.189-213, 1984b.

RIGHI, G. On a collection of Neotropical Megadrili Oligochaeta. I. Ocnerodrilidae, Acanthodrilidae, Octochaetidae, Megascolecidae. Studies on Neotropical Fauna and Environment, v.19, p.9-31, 1984c.

RIGHI, G. On a collection of Neotropical Megadrili Oligochaeta. II. Glossoscolecidae, Lumbricidae. Studies on Neotropical Fauna and Environment, v.19, p.73-87, 1984d.

RIGHI, G. Sobre o gênero Andiorrhinus (Oligochaeta, Glossoscolecidae). Boletim de Zoologia, v.10, p.123-151, 1985a.

RIGHI, G. Sobre Rhinodrilus e Urobenus (Oligochaeta, Glossoscolecidae). Boletim de Zoologia, v.9, p.231-257, 1985 b.

RIGHI, G.; GUERRA, A.T. Alguns oligochaeta do Norte e Noroeste do Brasil. Boletim de Zoologia, v.9, p.145-157, 1985.

SISTEMA brasileiro de classificação de solos. Brasília: Embrapa Produção de Informação; Rio de Janeiro: Centro de Pesquisas de Solo, 1999. 412p.

Received on October 30, 2008 and accepted on June 12, 2009

Pesq. agropec. bras., Brasília, v.44, n.8, p.934-939, ago. 2009 